\title{
Constraints to Vegetable Production among Women in Enugu North Agricultural Zone of Enugu State
}

Iwuchukwu J.C. and Uzoho U.C.

Department of Agricultural Extension

University Of Nigeria, Nsukka

Email: julieiwuchukwu@yahoo.com

\begin{abstract}
The study was carried out to ascertain constraints to vegetable production in Enugu Agricultural zone of Enugu State. A total of seventy one respondents were randomly selected for the study. A structured interview schedule was used to enlist information from the respondents. Statistical tools such as factor analysis and percentage were used to analyze the data obtained. The findings of the study were: Majority (88.7\%) grew fruited pumpkin (Telferia occidentalis). Majority (92.9\%) used communal land and family labour (95.7\%) to produce their vegetables. The major agronomic practices were direct sowing of seed (57.7\%), mixed cropping (56.3\%), organic manure (67.6\%), staking (8.5\%), broadcasting method of manuring (66\%) and cutting with knife (method of harvesting) (91.5\%). The mean annual income at main season was N6099.09 while that of off-season was N4387.8. Financial and agronomic/incentives problems were major constraints associated with vegetable production in the study area. It becomes important to transfer innovations on agronomic/management practices of vegetable to the area. This will boost output generally and increase income substantially thereby increasing their standard/level of living.
\end{abstract}

Keywords: Constraints vegetable women production.

\section{INTRODUCTION}

Vegetables are among the major dietary intake of our everyday life. Vegetables include African spinach, water leaf, fluted pumpkin, lettuce and cabbage. They are used wholly or partly as food. Vegetables are grown mainly for their leaves and they contribute to a balanced diet particularly among rural poor where animal protein is deficient. According to Shippers (2000), vegetables are important commodities for poor households because their prices are relatively affordable when compared to other food items. Also their production is increasingly targeted as a livelihood strategy as the level of unemployment rises.

The presence of vegetable in daily diet have been strongly associated with reduced risk for some forms of cancer, heart diseases, stroke and other chronic diseases (Prior and Cao, 2000). Some components of vegetables are strongly antioxidants and function to modify the metabolic activation and detoxification/disposition of carcinogens and even influence processes that alter the effect of tumor cells (Wargovich, 2000). The author further stated that diuretic actions of vegetables are specially important in cases of oedema or swellings, kidney and heart conditions. Vegetables prevent habitual constipation and keep the entire intestinal tract free from harmful germs (Plant Resources of Tropical Agriculture (PROTA), 2004). The juice 
extracted from fresh raw vegetables are highly beneficial as they furnish all the cells and tissues of the body with the elements and nutritional enzymes which they need (Akintayo, 1997). Fresh juices provide these elements in the manner in which they can be most easily digested and absorbed by the body.

Proteins, vitamins and minerals are important nutrients needed by the body. Unfortunately, most inhabitants of tropical countries consume considerably less meat, eggs and dairy products that will supply these nutrients (Food and Agriculture Organization (FAO), 1998). Vegetables serve as cheap supplement of these vital nutrients. This is because the composition of vegetable protein is only slightly different from that of the animal protein. Recent experiments show that animal protein may be readily replaced by vegetable protein (FAO, 2001).

It is a fact that planting materials/seeds needed for vegetable production is inadequate or unavailable. Schippers (2000) ascertained that farmers frequently express desire to try out other varieties, but have no access to a good supply source especially the improved varieties. This is because they grow almost all the seeds they use for planting. This has made output to remain poor and at subsistent level especially during dry season. Lots of vegetable waste due to poor storage and processing facilities. This has made vegetables especially leaf vegetable to be abundant (supply above demand and consequent waste/fall in price of the product) and scarce (demand above supply and consequent high price/refusal to purchase the product) at certain seasons of the year. There is need to stabilize demand and supply of the product so as to avoid waste, scarcity and year round availability of the product at reasonable and affordable price.

Furthermore, labour, land, water, pests and diseases related problems affect vegetable production. For example the increasing rural-urban migration has reduced agricultural labour force, our land tenure system inhibits expansion for increased production and dependable water sources which is needed for the production of vegetables all year round is lacking especially in rural areas where majority of farmers reside. Also pests such as nematodes, snails, aphids, stinkbug, leaf caterpillar and diseases like leaf spot, damping off attack vegetables. Some of these pests and diseases have significant adverse effect on yield and quality of shoots and leaves of vegetables produced and consequently on income of vegetable farmers.

It is against these backdrops that this paper sought to describe socio-economic characteristic and production dynamics of vegetable farmers in Enugu North Agricultural zone, with emphasis on agronomic practices employed by them, compare profit made during rainy (main) and dry (off) season and ascertain major problems associated with vegetable production in the area.

\section{METHODOLOGY}

The study was carried out in Enugu North Agricultural zone of Enugu state. The zone comprises of eight blocks from where four blocks (Uzouwani I, Uzo Uwani II, Nsukka II and Igbo-etiti) were purposively selected due to concentration of vegetable farmers in the areas.

Multi-stage random sampling technique was also used to select the respondents for the study as shown below:

Stage 1: Two circles were randomly selected from each of the blocks (containing about eight circles each) giving a total of eight circles.

Stage 2: From each of the selected circles containing about eight sub circles each, two sub circles were randomly selected from each of the circles. This gives sixteen sub circles for the study. 
Stage 3: Five respondents (vegetable farmers) were randomly selected from each of the sub circles thus giving a sample size of eighty respondents. However, only seventy--one interview schedule were completely filled and used for analysis.

A structured interview schedule was used to obtain relevant information from the respondents. The variables considered under the production dynamics of the respondents were extent, season, sources of farmland and labour used in vegetable production. In order to investigate their agronomic practices, types of vegetable produced, seed sowing method, cropping/planting system, weeding, manuring and harvesting were considered. Eleven obstacles to vegetable production were also investigated and their grand mean was used to represent the major item. A varimax rotated factor matrix was them employed to identify the most important obstacles to vegetable production in the area.

Data collected were analyzed using percentage, t-test and factor analysis (using kaiser's decision rule where a variable with coefficient of 0.30 and above is considered as having a high loading and may be used in naming a factor).

\section{RESULTS AND DISCUSSIONS}

\section{Production dynamics of vegetable farmers}

Data in Table 1 indicate that majority $(70.4 \%)$ of the respondents produced vegetables occasionally while $29.6 \%$ produced regularly. Also, $39.4 \%$ of the respondents produced vegetable during rainy season only, $31.0 \%$ produced both during rainy and dry seasons while $29.6 \%$ produced only during dry season.

Table 1 also shows that majority (92.4\%) of the respondents used communal land in growing their vegetables, $33.8 \%$ used school land, $30.9 \%$ used family land while $30 \%$ rented their farmlands. The respondents might have resorted to the use of communal land because of land scarcity and degradation problems. Growing crops on a communal land may not afford one free access to the land thereby stifling initiative towards development and management/maintenance of the land and the crops planted.

The major sources of labour for growing vegetables as indicated by the respondents in table 1 were family labour $(95.7 \%)$ and hired/paid labour $(85.9 \%)$. The use of family labour reduces production cost while that of paid/hired labour increases it. There is need to embark on cost and benefit analysis before using hired/paid labor especially in a small scale enterprise/farming to avoid loss. Exchange labour serves as a better alternative when family labour is not enough. Unfortunately this type of labour has not been well utilized by these farmers. 
TABLE 1: Production dynamics of vegetable farmers

\begin{tabular}{lcc}
\hline Production dynamics & Frequency & Percentage \\
\hline $\begin{array}{l}\text { Extent of vegetable production } \\
\text { Regularly }\end{array}$ & 21 & 29.6 \\
Occasionally & 50 & 70.4 \\
Season of vegetable production & & \\
Rainy & 28 & 39.4 \\
Dry & 21 & 29.6 \\
Both & 22 & 31.0 \\
* Sources of Farmland & & \\
Communal & 66 & 92.9 \\
School & 24 & 33.8 \\
Family & 22 & 30.9 \\
Rent & 21 & 29.5 \\
* Sources of labour & & \\
Family & 68 & 95.7 \\
Hired & 61 & 25.9 \\
Exchange & 18 & \\
* Multiple Responses & &
\end{tabular}

* Multiple Responses

\section{Agronomic practices of vegetable farmers}

Data in Table 2 show that majority $(88.7 \%)$, of the respondents produced fruited pumpkin while only $11.3 \%$ produced African spinach. This finding agrees with Akoroda (1990) who stated that among Igbos an indigenous leafy vegetables Telferia occidentalis (fruited pumpkin) and Amaranthus species (African spinach) are grown in women home garden and are considered to be women's crops.

Data in Table 2 also reveal that $57.7 \%$ of the respondents sowed their seed directly while $42.3 \%$ planted in nursery before they transplanted to the farm. Also the cropping/planting method used by $56.3 \%$ of the respondents was mixed cropping while $43.7 \%$ practiced sole cropping. These farmers must have adopted mixed cropping as a guard against crop failure. This finding is also in line with Odinaka (1997) who noted that the most common production practice in traditional farming is a mixed crop together with a staple food particularly yam.

Majority $(67.6 \%)$ of the respondents used organic manure while $31.0 \%$ use both organic and inorganic manure to fertilize their vegetable farms. The fact that organic manure is more accessible, affordable and boosts quality of vegetable as claimed by rural farmers might have contributed to the high percentage accruing from its usage. This puts question on whether the organic manure will supply all the nutrients nitrogen, phosphorus and potassium along with micronutrient and in the right quantity. A combination of organic and inorganic manure may be ideal in this regard which only $31.0 \%$ of the respondents used.

Broadcasting method of manuring was commonly used by the respondents $(66.2 \%)$ followed by side placement $(22.5 \%)$. Broadcasting method saves labour and time but may no be effective as the manure may be wrongly placed where they cannot be useful to the intended crop and where their contact with the crop may mar growth and development of the crop. These findings on 
manure and method of manuring are in contrast with schippers (2000) who opined that the maximum leaf yield in vegetable requires top-dressing with a nitrogen fertilizer and also manure that contains phosphonus and other nutrients needed for seed production.

Majority $(91.5 \%)$ of them did not stake their vegetables. Utilization of stakes provided by yams have been a common practice but in recent time use of pure stands are becoming more common (Schippers, 2000). Staking of vegetables especially fruited pumpkin promotes growth and yield of the crop. These findings tend to suggest that these vegetable farmers are yet to incorporate staking into their agronomic practices.

Cutting with knife was the method of harvesting used by majority $(88.7 \%)$ of the respondents while only $11.3 \%$ harvested their vegetables by hand picking. Harvesting should be done by pruning of the shoot rather than hand picking (Schippers, 2000) while cutting is better than hand picking that hinders development of side shoot. This shows that in as much as the majority of the respondents did not practice hand picking. They had not used the best method of harvesting (by pruning of the shoot). This may be as a result of ignorance.

TABLE 2: Percentage distribution of Agronomic practices of the respondents

\begin{tabular}{|c|c|c|}
\hline Agronomic practices & Frequency & Percentage \\
\hline \multicolumn{3}{|c|}{ Type of vegetable produced } \\
\hline Fruited pumpkin & 65 & 88.7 \\
\hline African spinach & 8 & 11.3 \\
\hline \multicolumn{3}{|l|}{ Seed sowing method } \\
\hline Sowing directly & 41 & 57.7 \\
\hline Nursery & 30 & 47.3 \\
\hline \multicolumn{3}{|l|}{ Cropping/ planting system } \\
\hline Mixed cropping & 40 & 56.3 \\
\hline Sole/mono cropping & 31 & 43.7 \\
\hline \multicolumn{3}{|l|}{ Type of manure } \\
\hline Organic & 48 & 67.6 \\
\hline Inorganic & 1 & 1.4 \\
\hline Both & 22 & 31.0 \\
\hline \multicolumn{3}{|l|}{ Manure application method } \\
\hline Side placement & 16 & 22.5 \\
\hline Ring placement & 8 & 11.3 \\
\hline Broad casting & 47 & 66.2 \\
\hline \multicolumn{3}{|l|}{ Weeding } \\
\hline Number than weeded & 71 & 100.0 \\
\hline Number that did/not weed & 0 & 0.0 \\
\hline \multicolumn{3}{|l|}{ Staking } \\
\hline Number that staked & 6 & 8.5 \\
\hline Number that did/not stake & 65 & 91.5 \\
\hline \multicolumn{3}{|l|}{ Harvesting method } \\
\hline Cutting with knife & 63 & 88.7 \\
\hline Hand picking & 8 & 11.3 \\
\hline
\end{tabular}




\section{Estimation of annual income derived from vegetable production during rainy and dry seasons}

Table 3 reveals that $60.5 \%$ of the respondents earned an annual income of N6001-N10,000 only from vegetable production during rainy season while $67.7 \%$ earned an annual income of $\mathrm{N} 4,000$ and below from vegetable production during dry season. The mean annual income was N6099.09 during rainy season and N4387.80 during dry season. Contrary to the finding, vegetable production during dry (off) season attracts higher income than that of rainy season because of the scarcity of the product during dry period and its abundance during rainy (main) season. However, this difference may account for the quantity and quality of vegetables produced in these two seasons.

It is also important to note that the annual income made in both seasons were poor. The use of hired/paid labour in their vegetable enterprise as indicated in Table 1 might be one of the reasons. This little income does not encourage or provide opportunities for the farmers to expand their farming enterprise and boost their standard/level of living but makes them perpetually poor.

TABLE 3: Percentage distribution of respondents based on estimated annual income

\begin{tabular}{llll}
\hline Estimated annual income $(\mathrm{N})$ & Frequency & Percentage & $\overline{\mathbf{X}}$ \\
\hline Rainy Season & & & \\
$\leq 2,000$ & 11 & 15.5 & \\
$2001-4000$ & 10 & 14.1 & \\
$4001-6000$ & 6 & 8.5 & \\
$6001-8000$ & 18 & 25.4 & \\
$8001-10,000$ & 25 & 35.1 & \\
$>10,000$ & 1 & 1.4 & \\
Dry season & & & \\
$\leq 2,000$ & 30 & 42.3 & \\
$2001-4000$ & 18 & 25.4 & \\
$4001-6000$ & 2 & 2.8 & \\
$6001-8000$ & 2 & 2.8 & \\
$8001-1000$ & 3 & 4.2 & \\
$>10,000$ & 16 & 22.5 & \\
\hline
\end{tabular}

\section{Problems/constraints to vegetable production}

Data in Table 4 indicate that financial (factor 1) and agronomic/incentive (factor 2) were major constraints associated with vegetable production in the area. The specific items contributing to financial constraints as shown in the Table are: labourious nature of vegetable production (0.96), incidence of diseases and pests (0.96), high cost of input (0.87), high cost of hired labour (0.74) and high transportation cost $(0.73)$. Contrary to the finding, vegetable production is not tedious/labourious when compared to other agricultural tasks involved in growing crops like yam. This high loading may be derived from their inability to use family labour only in producing their vegetable and consequent reliance on hired/paid labour. The incidence of diseases and pests included mosaic disease, damping off, leaf and stem rot and pests like nematodes, aphid, leaf caterpillars which constitute nuisance to vegetable farms and the cost involved in controlling them. The high cost of input include inability to purchase good seedlings/seed varieties and fertilizer for growing their vegetables. While high transportation cost include expenses incurred 


\section{Journal of Agricultural Extension}

Vol. 13 (1) June, 2009

in transporting farmers, labourers, seed/seedlings and vegetables to and from farms, homes and markets.

Specific items that loaded high under agronomic and incentive problems are: poor fertility of the soil (0.88), lack of water (0.84), lack of credit facilities (0.83), lack of improved seedlings/seeds for planting (0.74) and perishability/lack of storage facility (0.47). Poor fertility of the soil may arise because of land scarcity and difficulty involved in securing enough fertile land within their vicinity (family land) for vegetable production hence the use of communal land (Table 1). Lack of water may be seen in the inability to provide water for the crop and in the quantity needed especially during dry season. Difficulty and inability to secure loan, grant and over draft due to poor income and lack of collateral might have aggravated the lack of credit facility as constraint to vegetable production. Lack of improved seeds/seedlings may account for unreliability, unavailability or inability to secure seeds/seedlings that are fast growing with higher yield and are resistant to pests and diseases. This Akoroda (1990) noted that there has been resistant seeds/seedlings which has been only partially successful. Perishability/lack of storage facility may be seen from the fact that these farmers cannot store their vegetables especially during bumper harvest (rainy season). This may be due to lack of knowledge, competence and unavailability of storage facilities for vegetables.

TABLE 4: Constraints to vegetable production

\begin{tabular}{lll}
\hline Constraints & $\begin{array}{l}\text { Factor1 } \\
\text { Financial }\end{array}$ & $\begin{array}{l}\text { Factor } 2 \\
\text { Agronomic/incentives }\end{array}$ \\
\hline High cost of input & 0.87 & 0.25 \\
Lack of improved seed for planting & 0.30 & 0.74 \\
Labourious nature of vegetable & 0.96 & 0.16 \\
production & & \\
Lack of land & 0.18 & 0.87 \\
Poor fertility of the soil & 0.17 & 0.88 \\
Lack of water & 0.33 & 0.84 \\
High cost of hired labour & 0.74 & 0.43 \\
Lack of credit facilities & 0.37 & 0.83 \\
Incidence of diseases and pest & 0.96 & 0.16 \\
Perish ability/ lack of storage & 0.46 & 0.47 \\
facility & & \\
High transportation cost & 0.73 & 0.49 \\
\hline
\end{tabular}

\section{CONCLUSION/RECOMMENDATION}

This study has shown that vegetable farmers in Enugu North agricultural zone made poor income and used hired labour for their vegetable production. They produced only fruited pumpkin and African spinach. Also they did not stake their vegetables but applied mainly organic manure in their vegetable farms using broadcasting method. Financial and agronomic/incentive problems were major constraints to vegetable production in the study area.

Since income realized by these farmers from vegetable enterprise was poor and they lack credit facility. Considering the importance of vegetable in human life, there is need to involve government in providing grants, incentives and subsidies to these farmers so as to boost or expand their enterprise, derive enough income from it and depend on it as their livelihood activity. 


\section{Journal of Agricultural Extension \\ Vol. 13 (1) June, 2009}

Extension should encourage these farmers to delve into production of other vegetables like bitter leaf, lettuce, cabbage, curry and water leaf. This is because their concentration on only fruited pumpkin and African spinach means subjecting themselves to vicious cycle of poverty.

Extension should also transfer technologies on agronomic practices of vegetable production, especially in the areas of improved seeds/seedlings, staking and manuring to these farmers in order to improve output and income.

\section{REFERENCES}

Akintayo, E.T. (1997).A report on chemical composition and physiochemical properties of fluted pumpkin seed and seed oils. Nigeria: Chemistry Department, Ondo State University.

Akoroda, M.O. (1990). Ethnobotany of Telfairia occidentalis among Igbos of Nigeria. Economic Botany Vol. 44(1): 29-39.

Food and Agriculture Organization (FAO) (1998). The Global Plan of Action on Plant Genetic Resources for Food and Agriculture. Rome, Italy.

Food and Agriculture Organization (FAO) (2001). Traditional Food Plants. Rome, Italy.

Odinaka, N.I. (1997). Aspects of Seed Quality in Fluted pumpkin. M. Phil. Thesis Submitted to the Faculty of Agriculture and Forestry, University of Ibadan, Nigeria.

Plant Resources of Tropical Agriculture (PROTA) (2004). Vegetables. PROTA Foundation, Netherlands/Backhuys Publishers. Netherlands.

Schippers, R. (2000). African Indigenous Vegetables: An Overview of Cultivated Species. Natural Resources Institute/ACP-EU Technical Centre for Agricultural and Rural Cooperation. Chatham, UK.

Wargovich, H.M. (2000). The Useful Plants of West Tropical Africa. Vol. I. Kew: Royal Botanic Garden. 